\title{
EARLY WARNING SYSTEM (AWS) ANALYSIS WITH THE LOGIT MODEL FOR PREDICTING THE CONSUMER LOAN BANKS (BPRs)
}

\author{
Sufitri \\ Departemen Ekonomika dan Bisnis Sekolah Vokasi UGM \\ sufitri2002@yahoo.com
}

\begin{abstract}
Abstrak
Penelitian yang berjudul Perbandingan Early Warning System (EWS) untuk memprediksi Bank Perkreditan rakyat (BPR) di Indonesia bertujuan untuk menguji kemampuan model Logit dalam peringatan dini (EWS) dan untuk mengetahui model yang mempunyai kemampuan terbaik (model yang paling akurat) dalam memprediksi kebangkrutan BPR di Indonesia, sehingga dapat memberikan peringatan dini untuk mengatasi kebangkrutan. Penelitian ini menggunakan data sekunder berupa laporan keuangan audited yang diterbitkan oleh Bank Indonesia dan atau Otoritas Jasa keuangan tahun 2012 sampai dengan tahun 2017. Sampel penelitian adalah 20 bank perkreditan rakyat yang gagal/bangkrut dan 20 bank perkreditan rakyat yang termasuk kategori sangat sehat dengan asset kurang dari Rp 25.000.000.000. Data diolah dengan statistic deskriptif, korelasi variable independent (8 rasio keuangan) dan model estimasi regresi logit (probit untuk mengukur akurasi estimasi prediksi probabilitas kebangkrutan bank perkreditan rakyat di Indonesia. Kesimpulannya adalah koefisien antara 8 variabel independent berkorelasi lemah. Rasio keuangan yang paling berpengaruh pada prediksi kebangkrutan BPR adalah NPL, BOPO dan cash ratio (berkorelasi positif dengan prediksi kebangkrutan BPR sedang rasio ROA, PPAP dan asset berpengaruh negatif. Tingkat akurasi estimasi regresi logit sebesar $92,8 \%$.
\end{abstract}

Kata kunci, kebangkrutan, EWS, rasio keuangan, Logit.

\begin{abstract}
The study with the title of "Early Warning System Analysis" is used to predict the Consumer Loan Banks' potential bankruptcy. The samples are taken from the Consumer Loan Banks (BPR), publication by Bank Indonesia Financial Report, until October 2017, and from the very healthy BPRs with the assets of below twenty five billion rupiahs. The data are analyzed (1) by the use of descriptive quantitative technique to describe the samples (2) by means of correlation to find the relationship amongst the independent variables, that is, the eight financial ratios, and (3) by the use of probit regression to measure the accuracy of the model for predicting the BPR bankruptcy in Indonesia. The research concludes that (1) the Consumer Loan Banks (BPR), on average, have problems in capital, liquidity, operating cost, low-return asset, loan collectability, and low profitability, (2) the eight financial ratios have weak relation so that the regression model is made, (3) the financial ratios with positive impacts on predicting the BPR bankruptcy are NPL, LDR, BOPO, and CASH RATIO, whereas those with negative impacts are KPMM, ROA, PPAP, and ASSET. The level of accuracy of the estimated logit regression is $92.8 \%$.
\end{abstract}

Key words: bankruptcy, financial ratio, probit.

\section{Pendahuluan}

Sejak tahun 2014 industri Bank Perkreditan Rakyat (BPR) menghadapi persaingan yang semakin ketat karena terjadi pelambatan pertumbuhan ekonomi nasional, meningkatnya penyaluran kredit di industri bank dengan diberlakukannya kebijakan pemerintah yang mensyaratkan bank umum wajib menyalurkan kredit ke UMKM sebesar 20\% dari portfolio kreditnya, semakin menambah pelaku ekonomi yang melayani kredit UMKM (seperti koperasi, lembaga keuangan mikro, dan perusahaan teknologi keuangan). Sipendik.com melaporkan bahwa pertumbuhan ekonomi Indonesia tahun 2012 menurun pada level

30 | Jurnal Akuntansi, Ekonomi dan Manajemen Bisnis|Vol. 7 No.1, July 2019, 30-37|E-ISSN: 2548-9836 
6,29 dan 6,26 masing masing pada kwartal 3 dan kwartal 4. Pada tahun 2013 pertumbuhan ekonomi melambat pada level 5,78\% dan berdasarkan BPS, pertumbuhan ekonomi Indonesia di kuartal 4 pada tahun 2014 hanya tumbuh di level 5,21\% (year on year).

Dampak dari persaingan yang ketat tersebut adalah muculnya beberapa bank yang mengalami kesulitan likuiditas bahkan sampai dengan mengalami kepailitan. Salah satu penyebab kegagalan tersebut adalah adanya mis management dan moral hazard dari bank. Sampai dengan bulan oktober tahun 2017, Lembaga Penjamin Simpanan (LPS) sudah melikuidasi 83 bank, di mana 82 di antaranya merupakan BPR.

Semakin ketatnya persaingan ini tentunya dapat meningkatkan risiko kegagalan bank (Keeley, 1990), yang dalam kasus ini BPR lah yang justru memiliki peran penting pada pertumbuhan daerah (MeslierCrouzille, Nys, \& Sauviat, 2012). Indonesia, sebagai negara yang perekonomiannya didukung oleh UMKM, tentu BPR memiliki peran yang sangat penting karena BPR lah yang cukup mampu menjangkau usaha mikro dan kecil di Indonesia dalam pendanaan bisnis mereka (UMKM biasanya termasuk kelompok usaha yang non-bankable bagi Bank Umum); Selain itu, BPR memiliki potensi yang lebih besar untuk mengurangi kesenjangan informasi dengan pihak peminjam yang akhirnya dapat mengurangi biaya modal UMKM (Degryse \& Van Cayseele, 2000). Efisiensi tersebut berasal dari akses informasi BPR yang lebih baik dari bank besar (Meslier-Crouzille et al., 2012). Oleh karena itu, regulator perlu mengembangkan strategi untuk meminimumkan risiko kegagalan BPR.

Salah satu cara untuk meminimal kan kegagalan BPR adalah dengan menggunakan sebuah sistem peringatan dini atau Early Warning System (EWS). Dengan adanya deteksi dini, maka kebangkrutan dapat diantisipasi secara efektif dan efisien. EWS merupakan salah satu metode yang dapat memprediksi permasalahan potensial yang berhubungan dengan bank dan lembaga lainnya (Thomson, 1991). Untuk itu, perlu diuji determinan apa saja yang berpengaruh pada probabilitas kegagalan BPR. Dengan demikian, tujuan penelitian ini adalah menguji determinan kebangkrutan BPR.

\section{Tinjauan Literatur}

Model prediksi kebangkrutan (Beaver, 1996), mengidentifkasikan 30 rasio keuangan yang dianggap mewakili berbagai aspek yang relevan, dengan menggunakan teknik univariate discriminat analysis pada 79 perusahaan bangkrut dan 79 perusahaan tidak bangkrut, penelitian menyimpulkan bahwa rasio yang dapat menjelaskan kebangkrutan perusahaan dengan baik adalah adalah working capital funds flow to total asset dan net income to total asset dengan tingkat keakuratan sebesar $90 \%$ dan $88 \%$.

Hair dkk (1998) dalam Angelina (2004) menyatakan Multiple Discriminant Analysis (MDA) adalah teknik yang digunakan untuk memprediksi dan menjelaskan hubungan yang berpengaruh kuat terhadap kategori dimana objek tersebut berada, dimana variabel dependentnya merupakan sesuatu yang pasti dan variabel independennya matrik. Model MDA yang ada antara lain: Altman's Model oleh Edward Altman (1968). (Sufitri, 2009), Z Score Altman dapat dipergunakan untuk memprediksi kebangkrutan bank yang berada dalam Badan Pengawasan Perbankan Nasional), menyimpulkan $\mathrm{Z}$ score model dapat memprediksi kebangkrutan bank bank dalam Badan Pengawasan Perbankan Nasional. Kolari (2000) mengaplikasikan EWS pada bank komersiil terhadap 145 bank komersiil yang diasuransikan di Amerika Serikat pada tahun 1986.

Di Indonesia penelitian prediksi kebangkrutan mulai berkembang pada tahun 1990-an (dampak krisis moneter), antara lain oleh Wilopo (2001) dan Aryati dan Tanao (2002), yang memprediksi kebangkrutan bank dengan CAMEL, Adnan dan Taufik (2001) memprediksi kebangkrutan dengan Z-score, Angelina (2002) memprediksi kebangkrutan perusahaan perbankan dengan model regresi logit, analisis diskriminan dan trait recognition, dan masih banyak penelitian prediksi kebangkrutan.

Dapat disimpulkan bahwa terjadi ketidakkonsistenan antara hasil penelitian tentang rasio yang merupakan proksi dari kinerja keuangan perusahaan termasuk bank dalam memprediksi kebangkrutan. (Haddad, 2004): MDA layak dipergunakan sebagai model prediksi kebangkrutan bank umum di Indonesia. Sementara menurut (Suharman, 2007: model prediksi satu tahun mendatang lebih akurat yang membentuk model deskriminasi linier satu tahun sebelum risiko kegagalan usaha bank adalah rasio: likuidity ratio, NPL, CAR, ICR dan NIM). Platt (2002) menyimpulkan sebuah model yang terdiri 6 faktor yaitu Rasio: EBITDA to sales, Curent Assets to Current Liabilities, Net Fixed Assets to Total Assets, 
Long Term Debt to Equity, Notes Payble to Total Assets and the one year Cash Flow rate.

\section{Keaslian Penelitian}

Perbedaan penelitian ini dengan penelitian sebelumnya adalah: (a) obyek penelitian adalah Bank Perkreditan Rakyat Konvensional di Indonesia yang gagal (dinyatakan oleh regulator dalam hal ini Lembaga Penjamin Simpanan) dan BPR yang tidak gagal sampai dengan oktober 2017 (b) periode pengamatan dua tahun sebelum dinyatakan gagal/bangkrut dan dua tahun kedepan dari Bank Perkreditan Rakyat yang dinilai sangat sehat oleh Otoritas Jasa Keuangan periode tahun 2016 dan 2017 (c) menggunakan delapan rasio keuangan yang paling berpengaruh untuk memprediksi probabilitas kebangkrutan Bank Perkreditan Rakyat di Indonesia (d) Mengukur akurasi estimasi regresi Logit (probit) untuk Early Warning System (EWS) bagi probabilitas kebangkrutan BPR di Indonesia.

\section{Perumusan Masalah}

1 Bagaimana model estimasi regresi Logit (probit) terhadap NPL, LDR, KPMM, ROA, BOPO, PPAP, Kas Ratio, dan Asset dalam memprediksi probabilitas kegagalan BPR di Indonesia?

2 Rasio keuangan apa yang paling berpengaruh pada prediksi probabilitas kebangkrutan BPR di Indonesia?

3 Bagaimana pengaruh rasio keuangan terhadap prediksi probabilitas kebangkrutan BPR di Indonesia?

\section{Metode Penelitian}

\section{Kerangka Penelitian}
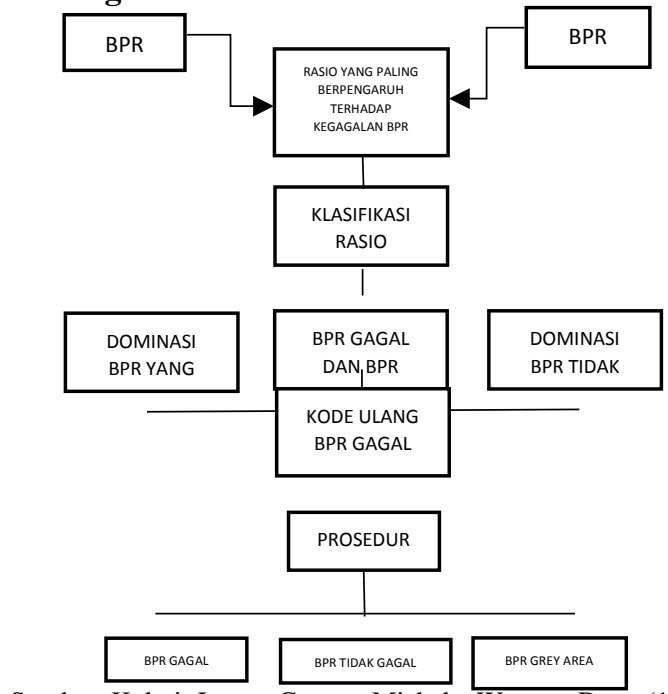

Sumber: Kolari, James, Caputo, Michele, Wagner, Drew (1996).
4. Berapa akurasi estimasi logit (probit) untuk memprediksi probabilitas kebangkrutan BPR di Indonesia?

\section{Landasan Teori}

Menurut Weston \& Copeland (1997), kebangkrutan adalah suatu kegagalan yang terjadi dalam perusahaan, jika perusahaan mengalami kegagalan ekonomi dan kegagalan keuangan.

Analisis logit adalah alat analisis regresi linier dimana variable dependennya nonmetric dan terbagi menjadi dua kelompok (biner), meskipun formulasinya dapat melebihi dua kelompok. (Hair, dkk, 1998). Formulasi model Regresi Logit:

Log Prob/ (1- Prob) $=\mathrm{a}+\mathrm{b} 1 \mathrm{Xi1}+\mathrm{b} 2 \mathrm{Xi} 2+\ldots+$ bnXn. Rasio keuangan yang dipergunakan dalam penelitian ini mengacu rasio keuangan dari Peraturan Otoritas Jasa Keuangan tahun 2011 tentang penilaian kinerja BPR dengan metode RGEC, sebagai berikut:
1. NPL
2. LDR
3. KPMM
4. ROA
5. BOPO
6. PPAP
7. Cash Ratio
8. Total Asset (Size)

\section{Hipotesis}

Hipotesis yang diajukan dalam penelitian ini adalah sebagai berikut:

NPL, KPMM, LDR, ROA, PPAP, BOPO, Cash Ratio, Aset berpengaruh negative terhadap probabilitas kebangkrutan BPR di Indonesia?

\section{Data dan Pengumpulan Data}

Penelitian ini menggunakan data sekunder berupa laporan keuangan yang diterbitkan oleh Lembaga Penjamin Simpanan (LPS) dan Otoritas Jasa Keuangan (OJK), audited, periode dua tahun sebelum BPR dinyatakan pailit dan dua tahun BPR masuk kategori sehat (penilaian atau pemberian rating oleh Info Bank).

\section{Populasi dan Sampel}

Populasi penelitian adalah industry BPR (konvensional) di Indonesia sampai dengan bulan oktober 2017 yaitu sebanyak 1.619 Bank Perkreditan Rakyat.

\section{Sampel}

Sampel penelitian diambil dengan metode Purposive Sampling, yaitu metode pemilihan sampel dengan menggunakan kriteria yaitu (BPR yang dinyatakan bangkkrut dan dilikuidasi oleh Lembaga Penjamin Simpanan (LPS), (b) BPR yang dinyatakan sehat oleh 
LPS (c) BPR termasuk dalam kategori asset (sebagai proxy ukuran/size) bank yaitu BPR yang ber asset kurang dari Rp25.000.000.000; (d) menyajikan laporan keuangan dua tahun sebelum BPR dinyatakan bangkrut dan dilikuidasi dan dua tahun dari tahun 201bagi BPR yang tidak bangkrut atau sehat yaitu periode tahun 2016 dan 2017.

Sampai dengan bulan oktober tahun 2017, terdapat 82 BPR yang dilikuidasi oleh Lembaga Penjamin Simpanan (LPS), dengan menggunakan kriteria sampel maka diperoleh sampel sebanyak 20 BPR yang dilikuidasi dan 20 BPR yang tidak gagal.

\section{Variabel Penelitian dan Definisi Operasional}

Penelitian ini menggunakan variable dependent berupa status BPR dan variable dummy, nilai 1 untuk BPR yang mengalami bangkrut (dilikuidasi) dan nilai 0 (nol) untuk BPR yang sangat sehat (tidak bangkrut). Sedang variable independent adalah:

$\mathrm{NPL}=$ total kredit bermasalah/total kredit $\times 100 \%$ LDR = total kredit /total Dana Pihak Ketiga $\mathrm{x} 100 \%$

$\mathrm{KPMM} / \mathrm{CAR}=$ Modal/Aktiva Tertimbang Menurut Risiko

ROA $=$ Net Income/Total Asset $\times 100 \%$

PPAP $=$ Kredit Bank x \% Kolektibilitas Kredit

$\mathrm{BOPO}=$ Biaya Operasional/Pendapatan operasional $\mathrm{x}$ $100 \%$

Cash Ratio $=$ Total Kas dan Setara Kas/Kewajiban Lancar x $100 \%$

Aset $($ size $)=$ Total Asset

Definisi operasional variable penelitian antara lain:

1. Status usaha BPR dikelompokan menjadi dua yaitu bank gagal (bangkrut) dan tidak gagal (sangat sehat), sesuai ketentuan Bank Indonesia.

2. NPL (Non Performance Loan), adalah rasio keuangan yang mencerminkan kualitas kredit suatu BPR, semakin tinggi NPL, berarti semakin rendah atau jelek kualitas kredit BPR tersebut, karena semakin banyak kredit yang bermasalah atau menunggak. Ketentuan besarnya NPL BPR saat ini sebesar 5\% (Peraturan Bank Indonesia)

3. LDR (Loan to Deposit Ratio), adalah rasio keuangan yang mencerminkan kemampuan BPR dalam menyalurkan kredit dari Dana PIhak Ketiga yang berhasil dihimpun oleh BPR. Ketentuan Bank Indonesia LDR sebesar $110 \%$.

4. KPMM/CAR, adalah rasio keuangan yang mencerminkan kemampuan modal BPR untuk menutup kemungkinan kerugian, menurut Peraturan Bank Indonesia besarnya CAR adalah $8 \%$.

5. ROA (Return On Aset), adalah rasio keuangan yang mencerminkan kemampuan BPR dalam menghasilkan net income aau laba bersih dari total asset yang dimiliki. Semakin tinggi ROA, berarti semakin efisien BPR dalam menggunakan dana atau asset yang dimiliki.

6. PPAP (Penyisihan Pengahapusan Aktiva Produktif atau Cadangan Kerugian Penurunan Nilai) adalah rasio keuangan yang mencerminkan berapa nilai kredit yang dihitung berdasarkan hasil evaluasi kredit debitur yang diberikan bank. Semakin besar rasio ini semakin jelek dan sebaliknya.

7. BOPO (Biaya Operasional/Pendapatan Operasional) adalah rasio keuangan yang mencerminkan tingkat efisiensi operasional bank, semakin tinggi rasio ini, berarti semakin tidak efisien operasional BPR.

8. Cash Ratio (CR) adalah rasio keuangan yang mencerminkan kemampuan BPR dalam memenuhi kewajiban keuangan jangka pendek (mengukur likuiditas BPR, semakin tinggi rasionberarti semakin likuid, tetapi CR yang terlalu tinggi mencerminkan rendahnya efisiensi penggunaan modal karena mencerminkan semakin banyak dana yang menganggur untuk suatu tingkat operasional BPR).

\section{Teknik Analisis \\ Teknik analisis}

Analisis statistic deskriptif dipergunakan untuk mendeskripsikan rasio keuangan bank perkreditan rakyat berupa Non Performance Loan (NPL), Loan to Deposit Ratio (LDR), (KPMM), Return On Asset (ROA), Prosentase Penghapusan Aktiva Produktif (PPAP), Biaya Operasional Pendapatan Operasional (BOPO), Cash Ratio (CR) dan Aset terhadap kebangkrutan BPR yang gagal (dilikuidasi oleh LPS) dengan variable dummy yang bernilai 1 (satu) bagi BPR yang bangkrut dan bernilai nol bagi BPRyang tidak gagal.

\section{Korelasi}

Korelasi antara variabel untuk mengukur dari variabel independen yang dipergunakan untuk memastikan bahwa antara variabel independen berhubungan atau tidak.

\section{Regresi Logit}

Regresi Logit dipergunakan untuk menganalisis model prediksi kebangkrutan Bank Perkreditan Rakyat di Indonesia dengan menggunakan rasio keuangan. Model Regresi Logit dalam penelitian ini adalah: $\mathrm{Y}=\mathrm{a}+\mathrm{b} 1 \mathrm{X} 1+\mathrm{b} 2 \mathrm{X} 2+\mathrm{b} 3 \mathrm{X} 3+\mathrm{b} 4 \mathrm{X} 4+\mathrm{b} 5 \mathrm{X} 5+\mathrm{b} 6 \mathrm{X} 6$ dan b7 X7

Dimana:

$\mathrm{Y}=\mathrm{BPR}$ gagal atau tidak gagal (bangkrut dan sangat sehat)

$\mathrm{a}=$ konstanta

$\mathrm{b}=$ koefisien korelasi

33 | Jurnal Akuntansi, Ekonomi dan Manajemen Bisnis|Vol. 7 No.1, July 2019, 30-37|E-ISSN: 2548-9836 
X1 ... Xn: Variabel independent

\section{Prediktor Kinerja keuangan sebagai Early Warning System (EWS)}

Kinerja keuangan dengan menggunakan rasio keuangan dapat dipergunakan sebagai predictor terhadap kemungkinan kebangkrutan atau kesuksesan Bank Perkreditan Rakyat, karena rasio keuangan dapat mempengaruhi kebangkrutan atau kesuksesan suatu usaha atau bisnis termasuk Bank Perkreditan Rakyat.

\section{Hasil Dan Pembahasan}

\section{Gambaran Umum Industri BPR di Indonesia}

Sampai dengan bulan Oktober tahun 2017, jumlah BPR di Indonesia 1.619 BPR. Dari jumlah tersebut sejumlah 82 BPR dinyatakan bangkrut dan dilikuidasi oleh Lembaga Penjamin Simpanan (LPS). Jika dilihat dari kategori BPR menurut Bank Indonesia, maka BPR yang dilikuidasi termasuk dalam kategori BPR yang asset lebih kecil dari Rp25.000.000.000;

\section{Statistik deskriptif}

Tabel 1 menyajikan statistic deskriptif bank gagal dan sangat sehat dengan 7 rasio keuangan. Dari tabel 1 diketahui bahwa jumlah data yang diolah sebanyak 78 buah. Variabel yang dipergunakan dalam penelitian ini adalah variable gagal adalah variable dummy yang bernilai satu jika Bank Perkreditan Rakyat mengalami kebangkrutan dua tahun kemudian, dan nol jika Bank Perkreditan Rakyat tidak gagal.

TABEL 1

STATISTIK DESKRIPTIF

\begin{tabular}{|l|c|c|c|c|c|c|c|c|c|}
\hline Stats & gagal & Npl & ldr & kpmm & roa & ppap & Bope & $\begin{array}{c}\text { cash } \\
\text { ratio }\end{array}$ & aset \\
\hline N & 78 & 78 & 78 & 78 & 78 & 78 & 78 & 78 & 78 \\
\hline Mean & 0.51 & 13.92 & 91.12 & 1142.64 & -1.36 & 4128.62 & 142.60 & 23.71 & $110,000,000$ \\
\hline Sd & 0.50 & 14.91 & 52.30 & 7716.53 & 21.55 & 25089.18 & 127.55 & 36.43 & $770,000,000$ \\
\hline Min & 0 & 0 & -33 & -537 & -78 & -381 & 0 & 0 & 129,080 \\
\hline p1 & 0 & 0 & -33 & -537 & -78 & -381 & 0 & 0 & 129,080 \\
\hline p25 & 0 & 4 & 75 & 2 & -2 & 100 & 78 & 7 & $9,153,069$ \\
\hline p50 & 1 & 7.5 & 86 & 15 & 2 & 100 & 91.5 & 15 & $26,900,000$ \\
\hline p75 & 1 & 20 & 95 & 26 & 5 & 100 & 133 & 25 & $33,300,000$ \\
\hline p99 & 1 & 62 & 356 & 63519 & 98 & 170182 & 740 & 234 & $6,820,000,000$ \\
\hline Max & 1 & 62 & 356 & 63519 & 98 & 170182 & 740 & 234 & $6,820,000,000$ \\
\hline
\end{tabular}

Mean NPL, sebesar 13,92 ini mencerminkan bahwa sebagian besar BPR menyalurkan kredit terlalu agresif dan kurang mengedepankan prinsip hati hati, sehingga rata rata tingkat kredit bermasalah sebesar 13,92\% yang berada di atas rata rata kentuan Bank Indonesia sebesar $8 \%$.
Mean LDR sebesar 91,12\%, mencerminkan rata rata BPR mampu menyalurkan kredit dari Dana Pihak Ketiga yang dihimpun, meskipun belum maksimal, sedang nilai minimum LDR minus 33 mencerminkan bahwa terdapat BPR yang tidak likuid, sehingga tidak dapat menyalurkan kredit. Nilai maksimum LDR di atas ketentuan Bank Indonesia sebesar 120\%.

Mean KPMM, sebesar 1142,64 dengan standar deviasi sebesar 7716,53. Hal ini mencerminkan bahwa rata rata BPR mengalami kesulitan modal. Minimum CAR minus 537 mencerminkan bahwa BPR tidak mampu menyiapkan modal yang ditentukan oleh Bank Indonesia yaitu minimum $8 \%$. Tingginya standar deviasi BPR sebesar 7716,53 mencerminkan tingginya risiko BPR yang mengalami kesulitan modal dari yang ditetapkan atau ketentuan penyediaan modal minimum oleh Bank Indonesia.

Mean ROA sebesar minus 1,36\% dan Minimum ROA minus $78 \%$, dan standar deviasi sebesar $21,55 \%$. Nilai minus pada ROA mencerminkan bahwa BPR tidak mampu menghasilkan laba dari asset yang dioperasikan, ROA minus $78 \%$ mencerminkan bahwa setiap Rp 100 total asset, BPR menderita rugi sebesar $\mathrm{Rp}$ 78. Sedangkan standar deviasi ROA sebesar $21,55 \%$ mencerminkan bahwa risiko tidak mendapatkan laba rata rata BPR 21,55\%.

Mean PPAP sebesar 4128,62 mencerminkan bahwa kolektivitas atau kualitas kredit BPR rendah, sehingga risiko penurunan nilai asset atau menurunnya kualitas aktiva produktif atau aktiva yang mampu menghasilkan return rendah. Tingginya PPAP mencerminkan menurunnya nilai asset yang mampu menghasilkan return dan pada saat yang sama akan meningkatkan risiko kredit (kualitas kredit turun) dan akan berdampak pada menurunnya efisiensi penggunaan modal ROA.

Mean BOPO sebesar 142,60 dan standar deviasi atau penyimpangan sebesar 127,55. Mean BOPO sebesar 142,60 mencerminkan bahwa efisiensi operasional BPR sangat rendah karena di atas ketentuan Bank Indonesia: BOPO maksimum sebesar $80 \%$ dari pendapatan. Mean BOPO 142,60 mencerminkan bahwa biaya operasional BPR lebih tinggi dari pendapatan operasional BPR, sehingga potensi rugi cukup tinggi, dan sekaligus menurunkan profitabilitas BPR. Mean CR sebesar 23,71\% artinya setiap Rp 100 kewajiban lancar, BPR mempunyai agunan berupa kas dan setara kas Rp 23,71, dan kemampuan membayar jangka pendek maksimum dari BPR sebesar 234 kali dari kewajiban keuangan jangka pendek. Standar deviasi cash ratio sebesar $36,43 \%$ mencerminkan 
bahwa risiko BPR mengalami kesulitasn likuiditas sebesar $36,43 \%$.

Variabel Aset sebagai proxy ukuran BPR, nilai maksimum asset sebesar Rp6.820.000.000 sedang nilai mean asset BPR sebesar Rp110.000.000 dan minimum asset sebesar Rp129.080 dan tingkat penyimpangan dari rata rata (standar deviasi) sebesar 770,000,000. Dari variable ukuran yang menggunakan indikator total asset, maka dapat dikatakan rata rata BPR mempunyai asset sebesar Rp 110.000.000 dan minimum asset sebesar Rp 129.080.

\section{Korelasi Variabel Independent}

Hasil olahan data dengan menggunakan STATA korelasi antara variabel independen, diketahui bahwa tidak ada hubungan yang kuat antara variable independen yang berjumlah 8 rasio keuangan. Korelasi antara LDR dengan NPL, sebesar 0,251 (lemah karena dibawah 0,06). Dapat disimpulkan bahwa korelasi antara variable independen lemah, sehingga layak untuk dikembangkan model regresi.

\section{Model Regresi Logit BPR di Indonesia}

Untuk mengetahui trend dari rasio keuangan dalam meprediksi kebangkrutan BPR di Indonesia akan dilakukan dengan estimasi regresi data panel probit dengan menggunakan model Random Effects.

Hasil olahan STATA model regresi Logit dari delapan rasio keuangan yaitu NPL, LDR, KPMM, ROA, PPAP, BOPO, CASH RATIO, dan asset, diketahui bahwa rasio NPL, BOPO dan cash ratio berpengaruh positif terhadap probabilitas kebangkrutan BPR di Indonesia. Semakin tinggi atau meningkat NPL, maka proporsi kredit yang bermasalah baik macet atau kurang lancar meningkat, sehingga risiko kredit meningkat dan akan berdampak pada penurunan profitabilitas sekaligus penurunan nilai asset. Penurunan profitabilitas dan asset akan berdampak pada penurunan return atau laba sehingga profitabilitas menurun dan bahkan dapat terjadi penyusutan/menyusutnya nilai asset bank. Peningkatan BOPO, mencerminkan peningkatan biaya operasi BPR untuk setiap rupiah pendapatan. Semakin tinggi BOPO, maka akan berdampak menipisnya laba atau margin yang kecil dan bahkan bisa menurunkan laba sebagai satu system. Meningkatnya Cash Ratio, disatu aspek, mencerminkan adanya kecukupan likuiditas bank, tetapi disisi lain, jika cash ratio terlalu tinggi, maka berarti banyak dana yang mengganggur, sehingga profitabilitas juga akan menurun.

Sementara variabel rasio keuangan ROA, PPAP dan size atau asset BPR di Indonesia berpengaruh negative atau mengurangi probabilitas kebangkrutan BPR di Indonesia. Tingginya profitabilitas ternyata tidak diikuti dengan peningkatan kesehatan bank. ROA berkorelasi negative dengan prediksi kebangkrutan BPR di Indonesia, sehingga semakin tinggi atau meningkatnya ROA berarti semakin menurunkan probabilitas kebangkrutan BPR. PPAP dan asset yang berkorelasi negative dengan probabilitas kebangkrutan BPR, ini mencerminkan semakin besar asset dan semakin besar penyisihan dana untuk penghapusan pihutang, maka akan semakin besar probabilitas BPR semakintidak gagal.

\section{Model regresi}

Model regresi prediksi kebangkrutan bank Perkreditan Rakyat di Indonesia adalah sebagai berikut:

$\mathrm{Y}($ gagal $/$ sangat sehat $)=573,25+0,86 \mathrm{NPL}-0,00$

$\mathrm{KPM}+$ 0,20 LDR - 2,99 ROA - 0,20 PPAP + 0,39 $\mathrm{BOPO}+$ 0,21 CASH RATIO -35,64 Asset.

\section{Hasil Uji Hipotesis}

Untuk menguji hipotesis dengan uji Logit diketahui bahwa variable yang mempunyai tanda sama dengan prediksi adalah: variable NPL, BOPO dan Cash Ratio dan yang tidak sama dengan prediksi adalah ROA, PPAP dan Size.

TABEL 2

\begin{tabular}{|c|c|c|c|c|c|c|}
\hline & NILAI & Z DARI & SIO & KEUAI & GAN & \\
\hline Random-effects & probit regre & ession & & Nuber & of obs & 75 \\
\hline Group variable: & ID & & & Nunber & of groups - & 39 \\
\hline Random effects & u_i Gaussi & & & Obs pe & group: & \\
\hline & & & & & $\min -$ & \\
\hline & & & & & avg - & 1.9 \\
\hline & & & & & $\max =$ & \\
\hline Integration met & thod: mvagher & mite & & Integr & tion pts. - & 12 \\
\hline & & & & Fald $c$ & $i 2(7)$ & 9.10 \\
\hline Log likelihood & --6.640241 & & & Prob > & chi2 & 0.2454 \\
\hline gayal & Coef. & Std. Err. & $z$ & $\mathrm{P}>|z|$ & [95\& Conf & . Interval] \\
\hline npl & 3.437423 & 1.295479 & 2.65 & 0.008 & .8983312 & 5.976515 \\
\hline kpma ta & -131.362 & 327.4532 & -0.40 & 0.688 & -773.1585 & 510.4345 \\
\hline $\bar{l} d r$ & .312335 & .247007 & 1.26 & 0.206 & -.1717899 & .7964599 \\
\hline roa & -1.3348 & .7153551 & -1.87 & 0.062 & -2.73687 & .0672703 \\
\hline ppap_ta & -2595.88 & 1189.995 & -2.18 & 0.029 & -4928.227 & -263.5333 \\
\hline bopo 0 & 90.87321 & 37.51431 & 2.42 & 0.015 & 17.34652 & 164.3999 \\
\hline size & 7.498344 & 3.93532 & 1.91 & 0.057 & -.214742 & 15.21143 \\
\hline - cons & -153.3123 & 75.92203 & -2.02 & 0.043 & -302.1167 & -4.50785 \\
\hline /lnsig $2 u$ & 3.383239 & 1.015702 & & & 1.392498 & 5.373979 \\
\hline signa u & 5.428263 & 2.75675 & & & 2.006213 & 14.68739 \\
\hline rho & .9671766 & .0322445 & & & .8009908 & .9953857 \\
\hline
\end{tabular}

Pada table 2 dapat disimpulkan bahwa: rasio keuangan NPL, BOPO dan Cash Ratio yang berpengaruh positif, sedangkan yang berpengaruh negative adalah rasio Return On Aset (ROA), PPAP dan TotalAset. 
1. NPL berpengaruh positif terhadap probabilitas kebangkrutan BPR.

2. LDR tidak berpengaruh terhadap probabilitas kebangkrutan BPR di Indonesia.

3. KPMM tidak berpengaruh terhadap probabilitas kebangkrutan BPR.

4. ROA berpengaruh negatif terhadap probabilitas kebangkrutan BPR

5. PPAP berpengruh negative terhadap probabilitas kebangkrutan BPR di Indonesia.

6. BOPO berpengaruh positif terhadap probabilitas kebangkrutanBPR

7. Cash Ratio berpengaruh positif terhadap probabilitas BPR.

8. Asset berpengaruh negative terhadap probabilitas kebangkrutan BPR di Indonesia.

Model Prediksi gagal (Kebangkrutan dengan Realisasi Gagal) Bank Perkreditan Rakyat di Indonesia.

Untuk mengukur keakuratan prediksi gagal dengan realisasi/fakta gagal, digunakan asumsi, jika hasil prediksi probabilitas gagal lebih dari 0,5, maka BPR dianggap gagal. Dengan asumsi jika hasil prediksi probabilitas gagal lebih dari 0,5 maka bank dianggap gagal, ada tiga hasil prediksi yang salah dari 78 prediksi. Ini artinya, kegagalan prediksi dari estimasi probit adalah sebesar 3,8\%. Dari 78 prdiksi. Berdasarkan tablel 1 dapat disimpulkan bahwa kegagalan prediksi dari estimasi logit (probil) adalah sebesar 3,8\% (3/78 x 100\%), dengan kata lain akurasi estimasi regresi logit (probit) untuk memprediksi probabilitas kebangkrutan industry BPR di Indonesia sebesar $96,2 \%$.

\section{Kesimpulan Dan Saran}

\section{Kesimpulan}

(1) Korelasi antara NPL, KPMM, LDR, ROA, PPAP, BOPO, Cash ratio dan asset lemah (antara variable ndependent terjadi multikol) sehingga layak untuk dibuat model regresi.lemah (antara variable ndependent terjadi multikol) sehingga layak untuk dibuat model regresi. (2) Persamaan Regresi kedelapan rasio keuangan tersebut adalah $=\mathrm{Y}$ $($ gagal $/$ sangat sehat $)=573,25+0,86 \mathrm{NPL}-0,00 \mathrm{KPM}$ + 0,20 LDR - 2,99 ROA - 0,20 PPAP + 0,39 BOPO + 0,21 CASH RATIO -35,64 Asset. (3) Hasil pengujian hipotesis tentang rasio keuangan yang berpengaruh pada probabilitas prediksi kebangkrutan BPR adalah:

NPL berpengaruh positif terhadap probabilitas kebangkrutan BPR di Indonesia. LDR tidak berpengaruh terhadap probabilitas kebangkrutan BPR di Indonesia. KPMM tidak berpengaruh terhadap probabilitas kebangkrutan BPRdi Indonesia. ROA berpengaruh negatif terhadap probabilitas kebangkrutan BPR di Indonesia. PPAP berpengaruh negative terhadap probabilitas kebangkrutan BPR di Indonesia. BOPO berpengaruh positif terhadap probabilitas kebangkrutan BPR di Indonesia. Cash Ratio berpengaruh positif terhadap probabilitas BPR di Indonesia. Asset berpengaruh negative terhadap probabilitas kebangkrutan BPR di Indonesia. (4) Tingkat akurasi estimasi regresi logit (probit) untuk memrpediksi probabilitas kebngkrutan BPR sebesar 92,2\%, (5) Model regresi logit dapat dipergununakan sebagai Early Warning System (EWS) bagi stakeholder, terutama bagi regulator, manajemen, pemilik dan desposan.

\section{Saran}

1. Untuk memperoleh kesimpulan yang lebih mendalam diperlukan pengujian dengan metode yang digunakan sebagai alat untuk menentukan kebijakan Bank Indonesia, Otoritas jasa Keuangan ataupun Lembaga Penjamin Simpanan, sehingga konsistensi alat dapat diketahui.

2. Model EWS perlu dikembangkan oleh Regulator untuk melakukan fungsi pembinaan Industri Jasa Keuangan termasuk Bank Perkreditan Rakyat karena cukup tinggi akurasinya.

\section{Daftar Pustaka}

A. Altman, E, L, 1968, Financial Ratios, Descriminat Analysis and The Prediction of Cororate Bankruptcy: The Journal of Finance, Vol 23, No 4,pp 589 -609

B. Adnan, Muhammad Akhyar dan Muhammad Imam Taufiq, 2001, Analisis Ketepatan Prediksi

C. Model Altman Terhadap Terjadinya Likuidasi Pada Lembaga Perbankan (kaussu Likuidasi di Indonesia), JAAI, Vol. 5 No.2

D. Andrew, W, 1986 "Logit versus Discriminant Analysis: A Specification Test and Aplication to Corporate Bankcrupties, Journal of Econometric, Vol 31, No 2, March.

E. Angelina, Liza, 2003 Perbandingan Early Warning System (EWS) untuk memprediksi Kebangkrutan Bank Umum di Indonesia, Buletin Ekonomi Moneter dan Perbankan.

F. Beaver, R.A. Agarwal, R Leach, 2002, Predicting Bankruptcy Resolution, Journal of Business, Finance and Accounting, 29, pp 497 $-518$

G. Cahyono, Adhi Wijaya, 2013'Prediksi Kebangkrutan Perusahaan Pertambangan Batubara Yang Listing DI Bursa Efek Indonesia, 
Periode 2011-2012Dengan menggunakan Analisis Model Z Score Altman

H. Degryse, H., \& Van Cayseele, P. (2000). Relationship Lending within a Bank-Based System: Evidence from European Small Business Data. Journal of Financial Intermediation

I. Garson, G.D, 2008, "Logistic Regression" http//www.2chass.nesu.edu/garson/PA765/Logi stic.htm 911 juli 2012)

J. Ghozali, Imam, 2005, Aplikasi Analisis Multivariate dengan Program SPSS, Badan Penerbit Universitas Diponegoro

K. Johan et al, 2012"Financial Distress Signaling \& Corporate Social Responsibility, World, Journal of Social Science, Vol.2 No 3, May 2012.

L. Kristin, Frenciska"Perbandingan Analisis Prediksi Kebangkrutan Menggunakan Model Altman ZScore dan Model Logistik (Studi Empiris Pada Perusahaan Non Keuangan yang terdaftar di BEJ", JOM Fekon Vol 1, No 2 Oktober 2014.

M. Murdayanti, Yunika \& Selina, 2002 "Penerapan Analisis Diskriminn Sebagai Alat Perusahaan Manufaktur Yang Terdaftar di Bursa Efek Indonesia Periode tahun 2009 -2013, Journal Admnistrasi Bisnis (JAB) Vol 15, No 1 Oktober 2004

N. Ohlson, J.A, 1980, Financial Ratios and the Probabilistic, Prediction of Bankruptcy, Jornal

O. Sufitri, 2007, Prediksi Kebangkrutan Bank Bank Pengikut Badan penyehatan Perbankan Nasional Dengan Z, Score Model.

P. Wild, J, John, Subranmayam, K.R., Helsey, Robert, 2009, Financial Statement Analysis, Mc. Graw-Hill

Q. Yuanita Eka, 2016, Potensi Kebangkrutan Bank Perkreditan Rakyat (BPR) Konvensional di Sumatera Barat, National Conference of Applied Science Engineering Business and Informtion Technology, Padang 